\title{
THE SHILUBANA JUDGMENT IN LIGHT OF TRANSFORMATIVE CONSTITUTIONALISM
}

\author{
By Serena Kalbskopf*
}

\section{Introduction}

In this essay I explore Karl Klare's notion of transformative constitutionalism explored in light of the case of Shilubana. ${ }^{1}$ Firstly, I define transformative constitutionalism and the circumstances present in the South African Constitution (Constitution) that give its interpretation a post liberal propensity are set out. This is followed by establishing why it is important to dull the distinction between law and politics, and by a consideration of the influence of legal culture when interpreting the law. Thereafter, I give a brief background of Shilubana. I argue that Shilubana was informed by some transformative constitutionalism principles as far as enhancing multiculturalism is concerned although it was limited by the legal culture of Justice Van Der Westhuizen. Lastly, I attempt to show that the final outcome of the case did effect desired social change envisaged through or by the project of transformative constitutionalism.

\section{Transformative constitutionalism}

After establishing the important role that adjudication plays in the making of law, ${ }^{2}$ Klare defines transformative constitution to mean a large scale revolutionary endeavour to cause social change by way of political processes grounded in law. ${ }^{3}$ His primary argument is not to convince the legal community that transformative constitutionalism is the correct legal interpretation but rather to open dialogue in general as to the nature of legal interpretation. ${ }^{4}$

Klare claims that essential features of the Constitution are among other things multiculturalism and gender identity, ${ }^{5}$ as well as a vision

Fourth year LLB student, University of Pretoria.

Shilubana \& Others v Nwamitwa 2008 (9) BLCR 914 (CC).

K Klare 'Legal culture and transformative constitutionalism' (1998) 14 South African Journal on Human Rights 147.

n 2 above 150 .

Klare (n 2 above) 152.

n 2 above 153 . 
for 'collective self determination'. ${ }^{6}$ From this, it would be expected that a document that departs from most classical liberal documents would establish a case for a post liberal reading of the Constitution. However, this is often not the case. ${ }^{7}$ Klare argues that the reason for this is the notion that the correct legal interpretation is a traditional liberal view and a post liberal interpretation is a political, non-legal view. ${ }^{8}$ In light of this, Klare highlights aspects of the constitution that would support a post liberal reading.

For purposes of this essay, the Constitutional facets that relate to social rights and the substantive conception of equality, affirmative state duties and multiculturalism are briefly examined. Social rights are furthered by the Constitution with a departure from an individual rights focus, to that of goals that should enhance communities. ${ }^{9}$ In addition to social rights, substantive equality is also a predominate feature. ${ }^{10}$ The government is called upon to promote human rights and equality - thus establishing positive state duties. ${ }^{11}$ Klare argues that the Constitution celebrates multiculturalism including respect for cultural tradition. ${ }^{12}$ With the presence of the substantive changes to the post 1994 Constitution, Klare states that this calls for a new judicial mindset to promote the values in the Constitution. ${ }^{13}$

Following from this, Klare's theory of judgement is set out by examining the relation between law and politics. Firstly, in terms of the idea of the Rule of Law, judges are seen as neutral enforcers of the law with no intimation of their own politics or subjective views, which are seen as synonymous. ${ }^{14}$ This raises the question as to the actions that should be taken by judges when they face a problem where there is no clear cut solution in a legal text. ${ }^{15}$ Notwithstanding the numerous approaches to suppress legal ambiguities, Klare argues that the strict separation between law and politics drawn by a traditional legal approach is a shortcoming and simplistic. ${ }^{16}$ His theory is an alternative that seeks to 'blur' the distinction between law and politics. ${ }^{17}$

The point of departure is that legal texts, regardless of their certainty, operate within legal constraint. ${ }^{18}$ Generally, legal texts do

Klare (n 2 above) 153.

Klare (n 2 above) 168.

n 2 above 152 .

Klare (n 2 above) 153

Klare (n 2 above) 153; Constitution of South Africa, 1996, sec 9(2).

Klare (n 2 above) 153; Constitution of South Africa, 1996, Preamble, secs 1(a),

$7(2) \& 39(1)(a)$

n 2 above 155

n 2 above 156.

Klare (n 2 above) 157.

Klare (n 2 above) 157.

n 2 above 158, 159 \& 161.

Klare (n 2 above) 159.

Klare (n 2 above) 160. 
not lend themselves to certain interpretations that provide for an initial impression of the nature of legal constraint. However, legal constraint does still bear an individual and cultural dimension. ${ }^{19}$ When a number of different scenarios are considered where the tension between legal constraint and political values of a judge are explored, Klare arrives at the conclusion that a judge's political values cannot be excluded from the interpretation of a legal text. ${ }^{20}$ As it is impossible to remove individual values from adjudication, the morals that underpin such adjudications should be evaluated and criticised. ${ }^{21}$ From the existence of the great role that judges have in the creation of law comes a sense of responsibility as far as candidness is concerned.

With regards to the role that judges play, the legal community needs to be more open about the politics that encompass the judicial process. Doing so, it can be argued, would fulfill the Constitution's call for organs of state to 'provide ... transparent, accountable and coherent government'. ${ }^{22}$ Moreover, the denial of the power that judges bear re-enforces legislative supremacy, which is not a characteristic of South Africa; a country in which the constitution is supreme. ${ }^{23}$ Therefore, central to the idea of transformative constitutionalism lies in the candidness of the more delicate line between law and political ideals that individuals hold. The final point that Klare makes after his examination of law and politics relates to the cultural aspect involved in legal constraint. For Klare legal culture refers to 'habits of mind and intellectual reflexes' or what argument judges may find convincing. ${ }^{24}$ Its origin lies in the failure of participants to recognise that the existence of what they may consider to be normal or convincing belongs specifically to their culture. ${ }^{25}$ This inhibits constitutional interpretation and slows down transformation. A critical examination of our legal culture is therefore appropriate. ${ }^{26}$ What follows below is a critical consideration of the link between South African legal culture and the resulting legal interpretation.

\section{The cultural context of the Shilubana decision}

South African legal culture is described as conservative where interpretation is a very structured rule bound approach. ${ }^{27}$ Klare uses

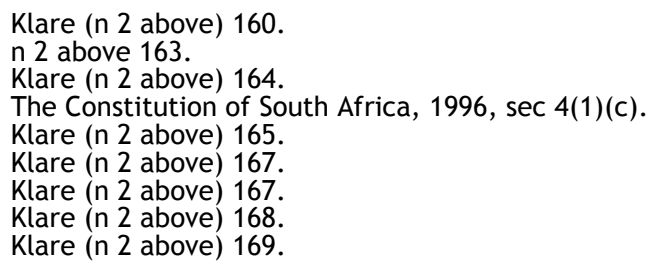


the United States of America's (US) legal culture to show a clear contrast between the two legal cultures. The US legal culture has a more policy based approach with far less emphasis on the reverence for law and the rejection of legal formalism as a result of the concretisation of realism. ${ }^{28}$ What results from South Africa's judicial conservatism is a resistance to a post-liberal Constitutional approach to interpretation and to the interpretive work of legal materials. ${ }^{29}$ It is due to this that it is feared that Constitutional transformation will be impeded, especially when a judge is restrained from legal interpretation that veers away from the formalistic culture. ${ }^{30}$

\section{The Shilubana case}

Before Klare's concept of transformative constitutionalism is viewed alongside the judgement in Shilubana, a brief background of the case is given. The Respondent, Mr Nwamitwa challenged Ms Shilubana's right to succeed Hosi Richard, the father of Mr Nwamitwa. Ms Shilubana was the daughter of Hosi Fofoza Nwamitwa who had no male heirs; as a result, succession was conferred to his younger brother Richard. In 1996, the Royal Family met and decided to confer Hosi onto Ms Shilubana and Hosi Richard further confirmed in the presence of a magistrate that upon his death, the position of Hosi would fall on Ms Shilubana. However, when Hosi Richard died Mr Nwamitwa sought an order in the High Court declaring him to be the rightful Hosi and not Ms Shilubana. ${ }^{31}$ Following from both the High Court's and Supreme Court of Appeal's finding in Mr Nwamitwa's favour, Ms Shilubana appealed before the Constitutional Court.

An interpretation of section 39(2) of the Constitution was the primary basis on which the decision was made, that is, the development of customary law is featured to solve the dispute. ${ }^{32}$ Thus, Klare's form of interpretation of a legal text would be most instructive and perhaps aid in a sound judgement. Transformative constitutionalism could be the recipe that could determine the ingredients and their respective amounts that would create a value laden result. Justice Van Der Westhuizen began by establishing what the customary law is, ${ }^{33}$ and it is within the judicial establishment of customary law that transformative constitutionalism would employ an interpretation that would enhance the idea of 'multiculturalism'

Klare (n 2 above) 169.

Klare (n 2 above) 171.

Klare (n 2 above) 171.

$D$ Cornell 'The significance of the living customary law for an understanding of law: Does custom allow for a woman to be Hosi?' (2009) 2 Constitutional Court Review 396-397. 32 Shilubana (n 1 above) para 42 \& 48.
33 Shilubana (as above) 43 . 
which it most sternly supports. ${ }^{34}$ To establish what measures should be used to decide what customary law is, the test in Van Breda $v$ Jacobs was reviewed. ${ }^{35}$ Van Der Westhuizen noted that customary law is an independent source of law and that the Van Breda test is thus not appropriate. ${ }^{36}$ In this context 'customary law' is a body of law, and not a source, and has developed as a result of the wants and customs of a distinct group of people. Thus, transformative constitutionalism would agree with such an approach as it promotes the true cultural tradition of the Valoyi community where customary law is recognised as a flexible and changing system of law. ${ }^{37}$ A test established under a judiciary system that sought to undermine many cultural traditions would have to be interpreted in a transformative way so as to promote democratic values. ${ }^{38}$

Notwithstanding Van Der Westhuizen's more post liberal approach to the determination of customary law, it is lacking a fundamental element of transformative constitutionalism - the recognition that a judge's own political and subjective experiences influence his or her decision. ${ }^{39} \mathrm{As}$ it is impossible for adjudication to take place without a judge's politics to be involved and specifically because this case involved a culture completely outside of Justice Van Der Westhuizen's point of reference, candidness about this would have enlightened the Constitution's call for organs of state to be more transparent. ${ }^{40}$ However, the judgement in Shilubana does have redeeming transformative constitutional elements as far as candidness about political involvement is concerned. This is seen in how firstly the amicus of the National Movement of Rural Women are invited to the case, ${ }^{41}$ and secondly how Van Der Westhuizen takes into account their submission. ${ }^{42}$ This shows some acknowledgement of Van Der Westhuizen's awareness of his individual values, which are likely lacking in the awareness of customary law.

The narrow view of the High Court that, because incorrect parties within the traditional leadership decided to make Ms Shilubana Hosi, the decision was illegitimate, was found to be incorrect. ${ }^{43}$ The more conservative strictly formalistic approach that the High Court adopted was a reflection of a legal culture that understands law as being a technical ritual. This is a failure to understand the context specific nature of customary law, and upholding the true nature of a culture's

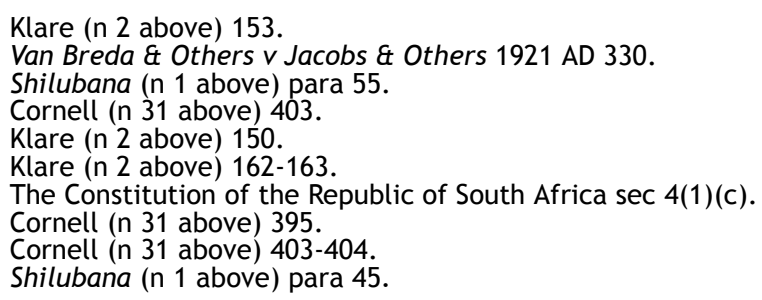


tradition is intrinsic with that culture's dignity. Further, the Constitution calls for a post-liberal reading that would call for development of law in order to realise the principle of dignity and a positive duty in the establishment of rights in adjudication, ${ }^{44}$ and the High Court and Supreme Court fail to do such by ignoring the context specific nature of customary law. The Constitutional Court in Shilubana, to an extent, rectifies this by recognising the contemporary developments of the law. Thus, Van Der Westhuizen used his interpretation within legal constraints to effect social change and a transformative decision followed.

\section{The question of transformation}

Although it can be argued that further transformation could have been achieved in the Shilubana case, one must raise the question: was there actual transformation? To answer the question one has to look at the change achieved in Shilubana in light of the past roles traditional leaders have had.

Before colonialism, traditional leaders played an important role within the social constructs of South Africa. ${ }^{45}$ However, colonialism and the apartheid reduced them to instruments of indirect rule, thereby lessening their power significantly. The apartheid government in particular, used traditional leaders to further their idea of segregation within constructed homelands. ${ }^{46}$

As the post apartheid era government strives to correct the ills of the past, giving traditional leadership a space in South Africa has been one aim of the government. Different takes on the role traditional leadership has made the decision of 'what role traditional leaders should play?' more difficult. Modernist thinkers focus on traditional leaders in relation to gender equality and its mechanism as the basis of rural patriarchy, whereas traditionalists focus on the role of traditional leaders as the heart of rural governance, political stability and rural development.

The question of whether transformation was indeed achieved by the judgement is found between the modernist and traditional approach. The Shilubana decision manages to find the middle ground between these two ideas by not maintaining the important role that traditional leaders have, but engaging in social change by removing some patriarchal elements of traditional leadership. Thus, Klare's idea of a 'long term project' is embodied in the middle ground

44 Klare (n 2 above) 156

45 SF Khunou 'Traditional leadership and independent bantustans of South Africa: some milestones of transformative constitutionalism beyond apartheid' (2009) 12

46 Potchefstroom Electronic Law Journal 4.

46 Khunou (n 45 above) 5. 
between two ideas that will eventually open the way to more transformation.

\section{Conclusion}

To conclude, it has been shown that transformative constitutionalism in adjudication encourages social change in the spirit of democratic values such as multiculturalism. Further, transformative constitutionalism is achieved through the candidness of the influence of politics in adjudication. In the Shilubana decision, multiculturalism was recognised - although probably not to its fullest possible extent due to the influence of the South African legal culture which is always a possible impediment to the realisation of transformative constitutionalism. Notwithstanding Shilubana's failures in a transformative constitutional sense, its final decision still affected positive social change. 